WOJCIECH ŁYSEK

Instytut Studiów Politycznych Polskiej Akademii Nauk

ORCID: 0000-0002-9180-5546

wojlys@gmail.com

\title{
Małe państwo a kryzys
}

Postawa Litwy, Łotwy i Estonii wobec protestów na Białorusi w sierpniu $2020 \mathrm{r}$.

\section{A small state and a crisis}

The attitudes of Lithuania, Latvia and Estonia

towards the protests in Belarus in August 2020

Słowa kluczowe:

Białoruś, kryzys polityczny, małe państwo, państwa bałtyckie
Keywords:

Belarus, political crisis, small state, Baltic States 
A small state and a crisis. The attitudes of Lithuania, Latvia and Estonia towards the protests in Belarus in August 2020

This article is dedicated to the attitudes of the Baltic States towards the protests in Belarus in August 2020. The analysis uses the category of a small state. It seems to best characterise the role of Lithuania, Latvia and Estonia in international relations. The first part of this article describes the relations of these three countries with Belarus before 2020. Then, the emphasis is put on the instruments and strategies which have been used by the Baltic States towards Belarus since the presidential elections in August 2020. The article discusses the role of a regional, expert, hidden subjectivity using multilateral formats, good services, entrepreneurial and silent diplomacy. In his considerations, the author presents the reactions of the authorities and societies. The article is based on state documents, analyses, politicians' speeches, press materials and literature on the subject. 


\section{Wstęp}

ałe państwa charakteryzują się takimi cechami jak terytorium do 80 tys. $\mathrm{km}^{2}$ i liczba ludności do $10 \mathrm{mln}^{1}$. Przejawiają one większą wrażliwość na ruchy migracyjne i posiadają szczupłe rezerwy surowców energetycznych. W porównaniu do innych aktorów międzynarodowych mają słabą pozycję i borykają się z relatywnym deficytem siły politycznej, militarnej i gospodarczej ${ }^{2}$. Przy niewielkim marginesie swobody muszą prowadzić ostrożną politykę, ponieważ cena ewentualnych błędów jest wysoka. Stosują zatem $\mathrm{w}$ relacjach międzynarodowych kilka typowych strategii: neutralność, udział w sojuszach, stawianie na bezpieczeństwo zbiorowe (strategie klasyczne) czy też współtworzenie bloków handlowych, związków politycznych oraz cichą i przedsiębiorczą dyplomację ${ }^{3}$ (strategie współczesne). Małe państwa uprawiają również tzw. dyplomację niszową, pełniąc rolę pośredników wyspecjalizowanych w konkretnych obszarach ${ }^{4}$. Od większych graczy odróżniają je ukrywanie swojej podmiotowości w obliczu zagrożeń i narastającego konfliktu oraz chętne wykorzystywanie formatów wielostronnych ${ }^{5}$.

Do małych państw zaliczają się Litwa, Łotwa i Estonia, położone między bardziej ludnymi i rozleglejszymi krajami jak Polska, Rosja i Białoruś. Wydaje się, że zasadne jest przyjrzenie się ich postawie podczas kryzysu politycznego na Białorusi po wyborach prezydenckich z sierpnia 2020 r. Warto

1 A. Ó Súilleabháin, Small states at the United Nations. Diverse perspectives, shared opportunities, International Peace Institute, New York 2014, s. 3: <https://www. ipinst.org/wp-content/uploads/publications/ipi_e_pub_small_states_at_un.pdf $\rangle$ [dostęp: $1 \mathrm{~V}$ 2021].

2 P. Bajda, Małe państwo europejskie na arenie międzynarodowej. Polityka zagraniczna Republiki Stowackiej w latach 1993-2016, Ośrodek Myśli Politycznej, KrakówWarszawa 2018, s. 57-58.

3 Cicha dyplomacja - metoda prowadzenia rokowań w sposób utajniony, aby osiągnąć porozumienie w szczególnie skomplikowanych kwestiach. Dyplomacja przedsiębiorcza - wykorzystanie swojego położenia, by wzmocnić własną pozycję ekonomiczną i polityczną.

4 M. Sułek, Małe państwa europejskie w świetle syntetycznych miar poteggi, [w:] Małe państwa Europy. Specyfika systemu politycznego i aktywności międzynarodowej, red. D. Popławski, Oficyna Wydawnicza „Aspra-JR”, Warszawa 2009, s. 29, 31-32.

5 P. Grudziński, Państwo inteligentne. Polska w poszukiwaniu międzynarodowej roli, Wydawnictwo „Adam Marszałek", Toruń 2008, s. 56. 
zadać pytanie, czy podejmowane przez nie działania wpisują się w przedstawiony zestaw strategii i instrumentów typowych dla małych państw.

\section{Zaangażowana Litwa}

Państwa bałtyckie wiąże z ziemiami białoruskimi długa historia i bliskość geograficzna. W szczególności dotyczy to Litwy, dla której poważnym wyzwaniem jest pogłębianie procesu integracji białorusko-rosyjskiej, ponieważ niepodległa Białoruś tworzy m.in. strefę buforową oddzielającą litewskie terytorium od bezpośredniej agresji ze strony Federacji Rosyjskiej. Istotne są również relacje gospodarcze, ponieważ ziemie białoruskie pełnią rolę hinterlandu dla litewskich (a także łotewskich) portów. Ze względu na bliskość i przystępną cenę korzysta z nich białoruski przemysł, a tranzyt wyprodukowanych na Białorusi towarów to istotne źródło dochodu Litwy ${ }^{7}$. Ważną kwestią sporną, która od wielu lat dzieli Wilno i Mińsk, jest budowana za środki z rosyjskich kredytów elektrownia jądrowa w Ostrowcu. Kontestująca tę inwestycję strona litewska wyraża przede wszystkim obawy odnośnie do kwestii bezpieczeństwa, m.in. okolicznej ludności ${ }^{8}$.

Chociaż jeszcze przed białoruskimi wyborami prezydenckimi na Litwie próbowano polepszyć relację z Mińskiem, to wydarzenia z sierpnia $2020 \mathrm{r}$. i zmasowane represje Alaksandra Łukaszenki przerwały wszelkie dyskusje i próby podejmowania dialogu9 ${ }^{9}$. Ton wypowiedzi litewskich polityków uległ

6 D. Wilczewski, Białorusini protestuja, Litwini wspieraja, „Przegląd Bałtycki” [online], 19 VIII 2020 [dostęp: 1 V 2021]: <https://przegladbaltycki.pl/16315,bialorusini-protestuja-litwini-wspieraja.html $>$.

7 K. Kłysiński, Skazani na wspótpracę. Uwarunkowania relacji Litwy i Łotwy z Białorusiq, Ośrodek Studiów Wschodnich, Warszawa 2013 (Komentarze osw, 99), s. 1, 6. W 2020 r. litewskie firmy zarobily na usługach transportowych $400 \mathrm{mln}$ euro. A. Pukszto, Stosunki ekonomiczne Biatorusi z Litwq i innymi krajami bałtyckimi w kontekście kryzysu migracyjnego oraz inicjatyw dyplomatycznych, [w:] Raport III. Gospodarka w cieniu polityki. Sytuacja ekonomiczna Białorusi, Studium Europy Wschodniej Uniwersytetu Warszawskiego, Warszawa marzec 2021, s. 68.

8 K. Raś, Państwa baltyckie wobec elektrowni atomowej w Ostrowcu na Białorusi, Polski Instytut Spraw Międzynarodowych, Warszawa 2020 (Biuletyn PISM, 172), s. 1-2.

9 A. Kuczyńska-Zonik, Międzynarodowa rola Litwy wobec kryzysu na Białorusi, Instytut Europy Środkowej, Lublin 2020 (Komentarze IEś, 247), s. 2. W 2019 r. doszło do serii wizyt amerykańskich dyplomatów w Mińsku. Więcej zob.: W. Łysek, Białoruś jako arena rywalizacji mocarstw. Stany Zjednoczone i Chiny wobec projektu 
zmianie, a 27 lipca prezydent wezwał przewodniczącego Rady Europejskiej Charles'a Michela do podjęcia działań w związku z pogarszającą się sytuacją w zakresie praw człowieka na Białorusi ${ }^{10}$. Litwa wraz z Łotwą i Estonią znalazła się wśród państw wyrażających solidarność z białoruskim społeczeństwem $^{11}$. 4 sierpnia minister spraw zagranicznych Linas Linkevičius rozmawiał ze swoim białoruskim odpowiednikiem Uładzimirem Makiejem, najprawdopodobniej o masowych protestach, ale nie można też odrzucić wersji, że władze w Wilnie chciały pełnić rolę pośrednika Waszyngtonu i były inspirowane przez amerykańską administrację ${ }^{12}$.

Kryzys na Białorusi stał się najpoważniejszym wyzwaniem dla bezpieczeństwa Litwy, która zaczęła się domagać od Unii Europejskiej wprowadzenia restrykcji wobec reżimu i ustanowienia funduszu na rzecz ofiar represji, argumentując to koniecznością przeciwdziałania łamaniu praw człowieka ${ }^{13}$. Jednocześnie 9 sierpnia w wygłoszonym z inicjatywy Wilna wspólnym oświadczeniu prezydentów Litwy i Polski władze Białorusi wezwane zostały do przestrzegania standardów demokratycznych, powstrzymania się od przemocy i poszanowania podstawowych wolności ${ }^{14}$.

integracji Federacji Rosyjskiej i Republiki Białoruś w latach 2019-2020, [w:] Rywalizacja Federacji Rosyjskiej na arenie międzynarodowej i jej konsekwencje dla bezpieczeństwa, red. M. Banasik, Wydawnictwo "Difin”, Warszawa 2020, s. 174-176.

10 R. Vilpišauskas, Lithuania, [w:] Baltic and Nordic responses to the 2020 post-election crisis in Belarus, ed. A. Sprūds, M. Andžāns, E. Djatkovič, Latvian Institute of International Affairs, March 2021 (Policy Brief), s. 25-26.

11 A. Kubilius, Białoruś: kilka uwag $w$ sprawach międzynarodowych, tłum. K. Korzeniewska, „Przegląd Bałtycki” [online], 20 IX 2020 [dostęp: 1 V 2021]: $<$ https://przegladbaltycki.pl/16472,bialorus-kilka-uwag-w-sprawach-miedzynarodowych.html $>$.

12 W. Jurasz, K. Turecki, Polska w światowej grze o Białoruś gra drugiie skrzypce, "Onet" [online], 11 VIII 2020 [dostęp: 1 V 2021]: <https://www.onet.pl/informacje/ onetwiadomosci/bialorus-wybory-prezydenckie-polska-w-swiatowej-grze-gradrugie-skrzypce/6odb2f5,79cfc278?fbclid=IwAR2DisE4GpTzCceH Krzn4cnKJqj6yqmM7ErJLp9TplocxebtKnYErQsqQM $>$.

13 K. Raś, Koniec ostrożnej przyjaźni Litwy z Białorusią, Polski Instytut Spraw Międzynarodowych, Warszawa 2020 (Biuletyn PISM, 205), s. 1.

14 Oświadczenie Prezydentów Andrzeja Dudy i Gitanasa Nausédy, „Prezydent” [online], 9 VIII 2020 [dostęp: 1 V 2021]: 〈https://www.prezydent.pl/aktualnosci/wydarzenia/art,1900,oswiadczenie-prezydentow-andrzeja-dudy-i-gitanasa-nausdy.html $>$; W. Jurasz, K. Turecki, Polska... 
Nie mniej istotny był skierowany do białoruskich władz trzypunktowy plan Gitanasa Nausèdy, ogłoszony 12 sierpnia po konsultacji z Andrzejem Dudą. Zakładał on m.in. powstrzymanie represji, zwolnienie zatrzymanych i rozpoczęcie dialogu ze społeczeństwem w celu wyjścia z kryzysu. Dzień później przedstawiony został jako wspólne stanowisko prezydentów Polski, Estonii, Litwy i Łotwy ${ }^{15}$. Mimo odrzucenia propozycji mediacji przez władze w Mińsku przywódcy tych państw podtrzymali swoją ofertę ${ }^{16}$.

10 sierpnia minister spraw zagranicznych Litwy wezwał do zaprzestania represji, a dzień później oświadczenia o podobnej treści wydały Trójkąt Lubelski ${ }^{17}$ i Ósemka Nordycko-Bałtycka ${ }^{18}$. Pierwsze z tych gremiów zaapelowało o niestosowanie siły oraz uwolnienie więźniów, proponując też mediacje $e^{19}$. Obszerniejsze oświadczenie wydała druga grupa - ministrowie podkreślili, że wybory nie były zgodne z międzynarodowymi standardami demokracji i praworządności, wezwali białoruskie władze do uwolnienia zatrzymanych oraz poszanowania praw i wolności, zapowiadając też wreszcie uważne śledzenie wydarzeń ${ }^{20}$. Przedstawione inicjatywy ukrywały podmiotowość małych państw w formatach wielostronnych.

15 Prezydenci zaapelowali o deeskalację, wstrzymanie użycia siły, uwolnienie zatrzymanych i dialog ze społeczeństwem. Wyrazili też poparcie dla stabilnej, demokratycznej, niezależnej oraz bogatej Białorusi i zaoferowali mediację. Presidents of Lithuania, Estonia, Latvia and Poland call for action on Belarus, „President Republic of Estonia" [online], 13 VIII 2020 [dostęp: 1 V 2021]: <https://www.president.ee/en/ meedia/press-releases/16115-presidents-of-lithuania-estonia-latvia-and-poland-call-for-action-on-belarus/index.html >.

16 D. Wilczewski, Białorusini...

17 Trójkąt Lubelski - platforma współpracy ministrów spraw zagranicznych Polski, Litwy i Ukrainy mająca na celu m.in. rozwój relacji politycznych i ekonomicznych oraz wsparcie Ukrainy w integracji z Unią Europejską i NATO.

18 Ósemka Nordycko-Bałtycka (Nordic-Baltic Eight) - nieformalna grupa pięciu państw nordyckich (Danii, Norwegii, Finlandii, Szwecji i Islandii) oraz trzech bałtyckich (Litwy, Łotwy i Estonii), w ramach której ustalane są wspólne interesy i cele.

19 R. Vilpišauskas, Lithuania..., s. 26.

20 Cyt. za: Joint Statement of Nordic-Baltic Foreign Ministers on recent development in Belarus, "Republic of Estonia. Ministry of Foreign Affairs”, 11 VIII 2020 [dostęp: $1 \mathrm{~V}$ 2021]: 〈https://vm.ee/en/news/joint-statement-nordic-baltic-foreignministers-recent-developments-belarus $>$. 
Wilno zaproponowało charakterystyczne dla małych państw dobre usługgi, umożliwiające dialog między białoruską władzą a społeczeństwem $^{21}$. Przykładem było udzielenie schronienia przedstawicielce opozycji Swiatłanie Cichanouskiej, istnieje bowiem duże prawdopodobieństwo, że jej przyjazd na Litwę był rezultatem rozmów litewsko-białoruskich ${ }^{22}$. Republika Litewska potwierdziła tym samym prowadzoną od lat politykę wspierania białoruskiego społeczeństwa obywatelskiego. Następnie Wilno odwiedzili zastępca sekretarza stanu USA Stephen Biegun ${ }^{23}$ i prezydent Francji Emmanuel Macron ${ }^{24}$, a tym samym wzrósł prestiż Litwy jako orędownika sprawy białoruskiej i aktywnego gracza międzynarodowego w sprawach wschodnich.

Reakcja Litwy na fałszerstwa wyborcze Łukaszenki wyprzedziła kroki podjęte przez $\mathrm{UE}^{25}$. Tamtejszy parlament już 18 sierpnia nie uznał go za prawowitego prezydenta i wezwał Komisję Europejską oraz państwa członkowskie do nałożenia sankcji na białoruskich urzędników odpowiedzialnych za represje. Litewskie ministerstwo spraw zagranicznych przedłożyło listę 118 białoruskich urzędników, których miały objąć państwowe obostrzenia, a ostatecznie pod koniec sierpnia wspólnie z Łotwą i Estonię zatwierdzono 30 osób objętych sankcjami za fałszowanie wyborów i stosowanie przemocy. W kolejnych tygodniach wykaz ten był aktualizowany ${ }^{26}$.

21 D. Popławski, Fenomen europejskiego państwa małego. Próba bilansu, [w:] Małe państwa..., s. 456.

22 W. Jurasz, K. Turecki, Polska...

23 We wrześniu w Waszyngtonie gościł Linas Linkevičius, zabiegając o stałą obecność amerykańskich żołnierzy na Litwie, co korelowało z wieloletnimi dążeniami państw bałtyckich. K. Raś, Koniec..., s. 2.

24 M. Jankowiak, A. Tichomirow, Białoruś trzy miesiąe po wyborach prezydenckich, „Przegląd Bałtycki” [online], 24 XI 2020 [dostęp: 1 V 2021]: <https://przegladbaltycki.pl/16839,bialorus-trzy-miesiace-po-wyborach-prezydenckich.html $>$.

2514 sierpnia ministrowie spraw zagranicznych państw UE ponowili apel o zaprzestanie przemocy. Decyzja o sankcjach zapadła 2 X 2020 r. Więcej zob.: Kalendarium sankcje UE wobec Białorusi, „Rada Europejska. Rada Unii Europejskiej” [online], 9 XI 2021 [dostęp: 18 XI 2021]: <https://www.consilium.europa.eu/pl/policies/sanctions/ restrictive-measures-against-belarus/belarus-timeline/ $>$.

26 A. Kuczyńska-Zonik, Międzynarodowa..., s. 1. 
Litwa prowadziła też intensywną politykę humanitarną. 11 sierpnia rozpoczęto stosowanie specjalnej procedury wjazdu dla obywateli Białorusi dotkniętych represjami. W oparciu o zeznania przybyłych pod koniec 2020 r. litewscy prokuratorzy wszczęli postępowanie przygotowawcze w sprawie zbrodni przeciwko ludzkości. Do końca roku pozwolenie na wjazd otrzymało 787 obywateli Białorusi, a 365 z nich wciąż mieszka na Litwie ${ }^{27}$.

Białorusini otrzymywali również aktywne wsparcie ze strony litewskiego społeczeństwa. Pierwsza akcja solidarności z protestującymi odbyła się 10 sierpnia, gromadząc kilkaset osób na jednym z wileńskich placów. W następnych tygodniach organizowane były kolejne publiczne demonstracje, a największe zainteresowanie wzbudził sformowany 23 sierpnia (w 31 rocznicę Bałtyckiej Drogi ${ }^{28}$ ) łańcuch solidarności, w którym obecny i byli prezydenci Litwy razem z ok. 50 tys. ludzi ustawili się od katedry w Wilnie aż do granicy z Białorusią 29 .

\section{Wyważona Łotwa}

Dotychczasowe relacje łotewsko-białoruskie zdominowane były przez kwestie gospodarcze, a mniej koncentrowały się na sprawach łamania praw człowieka na Białorusi ${ }^{30}$. Od przeszło dekady odbywały się coroczne wizyty dwustronne, a na 2020 r. zaplanowany był przyjazd Alaksandra Łukaszenki na Łotwę. Miała to być druga podróż białoruskiego prezydenta do UE po zniesieniu nałożonych na niego w 2016 r. sankcji, ale nie doszła do skutku ze względu na pandemię CoviD-19 ${ }^{31}$.

Ryga miała ambicje wyspecjalizowania się na forum unijnym w zakresie kontaktów gospodarczych $\mathrm{z}$ Mińskiem ${ }^{32}$. Można powiedzieć o prowadzeniu przez Łotwę dyplomacji przedsiębiorczej, polegającej na wykorzysta-

R. Vilpišauskas, Lithuania..., s. 27.

28 Bałtycka Droga (Bałtycki Łańcuch) - masowy protest ok. 2 mln mieszkańców Litwy, Łotwy i Estonii zorganizowany 23 VIII 1989 r., w rocznicę podpisania paktu Ribbentrop-Mołotow.

29 D. Wilczewski, Białorusini...; A. Kuczyńska-Zonik, Międzynarodowa..., s. 1.

30 K. Kłysiński, Skazani..., s. 7.

31 E. Djatkoviča, Latvia, [w:] Baltic and Nordic responses..., s. 21.

32 Tamże. 
niu portów w Windawie i Rydze dla wzmocnienia swojej pozycji na arenie międzynarodowej. Przemawia za tym fakt, że sektor transportu i logistyki odpowiadał w 2011 r. za ok. 13 proc. łotewskiego PKB, a towary z Białorusi stanowiły ponad 50 proc. ogólnej wartości tranzytu ${ }^{33}$ i około jednej piątej tranzytu kolejowego Łotwy. Obecność białoruskiego kapitału jest dla tego państwa istotnym czynnikiem gospodarczym $\mathrm{w}$ wymiarze regionalnym, a zamieszkany przez mniejszość białoruską najbiedniejszy region kraju, Łatgalia, skutecznie współpracuje $\mathrm{z}$ obwodem witebskim, nawet $\mathrm{w}$ trakcie pandemiii ${ }^{34}$.

Po wyborach prezydenckich na Białorusi współpraca Rygi z Mińskiem została ograniczona do minimum. Łotewskie władze potępiły oszustwa wyborcze i działania sił porządkowych. By zachować kanały komunikacji, postawiono jednak na wstrzemięźliwy ton ${ }^{35} \mathrm{i}$ dopiero po tajnej inauguracji Alaksandra Łukaszenki z 23 września 2020 r. Ryga zakomunikowała, że nie uznaje jego zwycięstwa. Parlament wydał wówczas oświadczenie o braku legitymizacji Łukaszenki do sprawowania funkcji prezydenta od 1 października. Nie wspomniano jednak o Swiatłanie Cichanouskiej, a do jej wizyty na Łotwie doszło dopiero w listopadzie 2020 r. Część członków Białoruskiej Rady Koordynacyjnej ${ }^{36}$ otrzymała tam azyl, ale nie wydano w tej sprawie żadnych oficjalnych komunikatów.

Łotwa wstrzymała proces rozwijania kontaktów gospodarczych na rzecz wsparcia dla społeczeństwa obywatelskiego na Białorusi ${ }^{37}$, a społeczeństwo

K. Kłysiński, Skazani..., s. 2-3.

34 A. Kuczyńska-Zonik, Sankcje Unii Europejskiej wobec Białorusi i ich wpływ na gospodarki Litwy i Łotwy, Instytut Europy Środkowej, [Lublin] 8 VII 2021 (Komentarze IES, 419), s. 2.

35 E. Djatkoviča, Latvia..., s. 20.

36 Rada Koordynacyjna - organ utworzony 18 VIII 2020 r. z polecenia Swiatłany Cichanouskiej. W założeniu miał koordynować akcję protestacyjną i prowadzić negocjacje z władzami. P. Usov, Zadania białoruskiego ruchu demokratycznego w perspektywie końca epoki Łukaszenki, [w:] Raport I. Białoruś 2021: perspektywa zmiany, Studium Europy Wschodniej Uniwersytetu Warszawskiego, Warszawa marzec 2021, S. 74 .

37 Wzorcowym przykładem tej zmiany jest elektrownia jądrowa w Ostrowcu. Uruchomiono ją 7 XI 2020 r., ale już 8 listopada stwierdzono problemy techniczne i tymczasowo ją wyłączono. Scenariusz ten wpisywał się w litewskie ostrzeżenia i uzasadniał decyzję o wstrzymaniu handlu energią z Białorusią. Łotwa zdecydowała się na taki krok 25 VIII 2020 r., a Estonia w geście solidarności 
zachęcane było przez władze do wspierania Białorusinów. Jednocześnie jednak obawiano się spadku obrotów handlowych i utraty przychodów z tran$z t_{u}{ }^{38}$. Mińsk groził, że w zakresie eksportu wyrobów petrochemicznych zastąpi dotychczas wykorzystywane porty bałtyckie rosyjskim w Ust-Łudze ${ }^{39}$. Mimo że litewskie i łotewskie porty znajdują się bliżej białoruskich zakładów, co obniża koszty transportu ${ }^{40}$, to przeważyły tu racje polityczne, przez co Białoruś traci finansowo, a dodatkowo pogłębia uzależnienie od Federacji Rosyjskiej. Tracą i będą tracić także państwa bałtyckie, szczególnie gdy wstrzymany zostanie tranzyt towarów z Ukrainy i Turcjii ${ }^{41}$.

W wymiarze gospodarczym bilans ostatnich działań Łotwy względem Białorusi jest niejednoznaczny. Udało jej się przyciągnąć uciekających stamtąd przedsiębiorców: do października 2020 r. ok. 70 firm rozważało przeniesienie działalności z Białorusi na Łotwę, a ostatecznie decyzję taką podjęło $17^{42}$. Jednocześnie nałożone na Białoruś sankcje nie będą odczuwalne dla łotewskiej gospodarki ${ }^{43}$, ale dotknie ją przekierowanie eksportu białoruskich wyrobów petrochemicznych ${ }^{44}$.

Ze względu na powolny proces decyzyjny w UE Łotwa wydała zakaz wjazdu dla ponad 150 białoruskich urzędników, a stosunki dyplomatyczne najwyższej rangi uległy zawieszeniu ${ }^{45}$. Ambasada w Mińsku kontynuowała

z pozostałą dwójką wstrzymała kontakty z Mińskiem na tym polu. Epizod ten wyraźnie oddaje różnice w podejściu państw bałtyckich do Republiki Białoruś. M. Jankowiak, A. Tichomirow, Białoruś...; D. Lebioda, Wpływ białoruskiej elektrowni jądrowej w Ostrowcu na kraje bałtyckie, „Przegląd Bałtycki” [online], 19 V 2021 [dostęp: 29 V 2021]: <https://przegladbaltycki.pl/17344,wplyw-bialoruskiej-elektrowni-jadrowej-w-ostrowcu-na-kraje-baltyckie.html $>$.

38 E. Djatkoviča, Latvia..., s. 22.

39 M. Paszkowski, Białoruś i Ukraina: nowy rynek zbytu dla amerykańskiej ropy naftowej, Lublin 2020 (Komentarze IEŚ, 180), s. 1.

40 K. Kłysiński, Skazani..., s. 6.

41 A. Pukszto, Stosunki..., s. 68.

42 E. Djatkoviča, Latvia..., s. 22.

43 A. Kuczyńska-Zonik, Sankcje..., s. 2.

44 Taż, Morze z widokiem na przyszłość. Potencjał i rozwój państw bałtyckich, Instytut Europy Środkowej, Lublin 2021 (Komentarze IES, 397), s. 1.

45 Podczas hokejowych mistrzostw świata w Rydze, których organizacji ze względu na sytuację polityczną została wcześniej pozbawiona Białoruś, mer miasta zastąpił flagę Republiki Białoruś biało-czerwono-białą. W konsekwencji Mińsk 
natomiast działania na rzecz wspierania białoruskiego społeczeństwa. Jej pracownicy wraz z korpusem dyplomatycznym odwiedzili w domu laureatkę Nagrody Nobla Swietłanę Aleksiejewicz i towarzyszyli opozycjonistom przy składaniu kwiatów w miejscu, gdzie zginęli protestujący ${ }^{46}$.

Należy również wspomnieć o wydaniu przez łotewskie władze 200 tys. euro na pomoc medyczną i usługi prawne dla Białorusinów oraz utrzymanie alternatywnych środków przekazu. Setki Łotyszy wyrażały też poparcie dla białoruskiego społeczeństwa, maszerując wzdłuż granicy z Białorusią ${ }^{47}$.

\section{Wstrzemięźliwa Estonia}

Estonia ze względu na niską intensywność kontaktów dwustronnych z Białorusią ${ }^{48}$ skoncentrowała się na działaniach za pośrednictwem organizacji międzynarodowych ${ }^{49}$. Przejmując w styczniu 2020 r. miejsce niestałego członka Rady Bezpieczeństwa ONZ, estońscy dyplomaci obiecali bronić na tym forum interesów mniejszych państw. Taka postawa inspirowana była przykładem Litwy, która w 2014 r. aktywnie reprezentowała Ukrainę. Powyborczy kryzys na Białorusi stał się okazją do spełnienia obietnic, wobec czego Estonia zainicjowała w Radzie dyskusję nt. wydarzeń z 18 sierpnia ${ }^{50}$. Nieoficjalne spotkanie tego gremium w tzw. formule Arrii odbyło się 4 września ${ }^{51}$.

wydalił wszystkich łotewskich dyplomatów. Białoruś wyrzuca ambasadora i prawie caly personel dyplomatyczny Łotwy. Łotwa odpowiada tym samym, „Onet” [online], 24 V 2020 [dostęp: 29 V 2021]: 〈https://www.onet.pl/informacje/onetwiadomosci/ bialorus-wyrzuca-ambasadora-i-prawie-caly-personel-dyplomatyczny-lotwy-lotwa/ y41zo3e, 79 cfc278>.

46 E. Djatkoviča, Latvia..., s. 20, 22.

47 Baltic nations form human chains in support of Belarus protests, "Deutsche Welle" [online], 23 vIII 2020 [dostęp: 1 V 2021]: <https://www.dw.com/en/balticnations-form-human-chains-in-support-of-belarus-protests/a-54667005 $\rangle$.

48 Tamże.

49 I. Tarand, Estonia, [w:] Baltic and Nordic responses..., s. 10.

50 K. Haugevik i in., Small states, different approaches. Estonia and Norway on the UN Security Council, International Centre for Defence and Security, Tallinn 2021, s. 7, 12: <https://icds.ee/wp-content/uploads/2021/11/ICDS_EFPI_Report_Small_States_ Different_Approaches_Haugevik_Kuusik_Raik_Schia_November_2021.pdf $\rangle$ [dostęp: 18 XI 2021].

51 D. Szacawa, Małe państwa Europy Pótnocnej w Radzie Bezpieczeństwa ONZ, Instytut Europy Środkowej, Lublin 2021 (Komentarze IEŚ, 370), s. 1. 
$\mathrm{Na}$ forum UE Estonia wzmacniała natomiast swoją pozycję w regionie Partnerstwa Wschodniego ${ }^{52}$. Warto tu podkreślić, że członkostwo w organizacjach euroatlantyckich ma dla tego kraju kluczowe znaczenie ${ }^{53}$. W $2016 \mathrm{r}$. Tallin poparł zniesienie większości unijnych sankcji wobec Białorusi, a w czasie estońskiej prezydencji w drugiej połowie 2017 r. przedstawiciele władz w Mińsku zostali zaproszeni do udziału w wydarzeniach organizowanych w ramach Partnerstwa Wschodniego, wśród których na szczególną uwagę zasługuje Forum Społeczeństwa Obywatelskiego ${ }^{54}$. W listopadzie 2020 r. estoński minister spraw zagranicznych przypominał, że „społeczność międzynarodowa [...] musi nadal wzywać władze Białorusi do dialogu z obywatelami w celu przeprowadzenia wolnych i uczciwych wyborów". Akcentował, że jednym z głównych celów Tallina jest zapewnienie przestrzegania prawa międzynarodowego oraz zwracanie uwagi na naruszenia praw człowieka ${ }^{55}$.

Podobnie jak władze innych państw bałtyckich estoński rząd w oświadczeniu z 18 sierpnia nie uznał rezultatu wyborów na Białorusi i wyraził wsparcie dla białoruskiego społeczeństwa, deklarując na ten cel 100 tys. euro i opowiadając się za sankcjami wobec winnych przemocy i fałszerstw ${ }^{56}$. W przeciwieństwie do łotewskich i litewskich parlamentarzystów estońscy posłowie nie podjęli jednak uchwały o braku legitymacji Alaksandra Łukaszenki do sprawowania funkcji prezydenta.

Współdziałając z Litwą i Łotwą, rząd Estonii przyjął listę trzydziestu osób, którym zakazano wjazdu na terytorium kraju. W odróżnieniu

52 M. Mardisalu-Kahar, Estonia and the Eastern Partnership: the view from Tallin, "European Council on Foreign Relations" [online], 19 V 2015 [dostęp: 18 XI 2021]: <https://ecfr.eu/article/commentary_estonia_and_the_eastern_partnership_the view_from_tallinn3036/>.

53 K. Haugevik i in., Small..., s. 18.

54 Political relations, "Embassy of the Republic of Belarus to the Republic of Estonia” [online, dostęp: 18 XI 2021]: 〈https://estonia.mfa.gov.by/en/bilateral_relations〉.

55 Cyt. za: The UN Security Council to discuss the issue of Belarus tomorrow at Estonia's initiative, "Republic of Estonia. Ministry of Foreign Affairs" [online], 10 XI 2020 [dostęp: 1 V 2021]: 〈https://vm.ee/en/news/un-security-council-discussissue-belarus-tomorrow-estonias-initiative\#: :text=You $\% 20$ are $\% 20$ here- $\% 20>$.

56 K. Kallaste, H. Wright, Estonian government does not recognize Belarus election results, „Eesti Rahvusringhääling” [online], 18 XI 2020 [dostęp: 18.11.2021]: <https://news. err.ee/1125073/estonian-government-does-not-recognize-belarus-election-results $>$. 
od pozostałych państw bałtyckich, które nałożyły sankcje bezterminowo, określił jednak czas ich obowiązywania na pięć lat ${ }^{57}$. W październiku 2021 r. - w geście solidarności z Polską i Litwą, które na żądanie władz Białorusi ograniczyły liczbę pracujących tam dyplomatów - estońskie władze $\mathrm{w}$ porozumieniu z innymi państwami UE wezwały swoją ambasador w Mińsku na konsultacje.

Akcje solidarności z białoruskim społeczeństwem były $\mathrm{w}$ Estonii mniej widoczne niż $\mathrm{w}$ pozostałych państwach bałtyckich. $\mathrm{W}$ Tallinie, $\mathrm{m}$. in. ze względu na niekorzystne warunki atmosferyczne, zebrało się zaledwie 1,5 tys. osób. Zabrakło tu szerszego zainteresowania Białorusią jak na Litwie czy aktywności mniejszości białoruskiej jak na Łotwie ${ }^{58}$.

\section{Konkluzje}

Postawione $\mathrm{w}$ artykule pytanie o wykorzystywanie przez państwa bałtyckie strategii i instrumentów typowych dla państw małych w znacznej mierze znajduje potwierdzenie w reakcjach na białoruski kryzys polityczny. W działaniach Litwy, Łotwy i Estonii możemy zauważyć niszową i cichą dyplomację, ukrytą podmiotowość z wykorzystaniem formatów multilateralnych oraz dobre usługi.

Najbardziej zauważalna jest dyplomacja niszowa. Z racji położenia i wspólnej historii rolę eksperta ds. Białorusi odgrywa przede wszystkim Litwa i tym też należy wyjaśniać łatwe przejęcie przez Wilno roli głównego promotora białoruskiej opozycji. Rozpatrując niszową dyplomację w kontekście przedmiotowym, wypada również wspomnieć Litwę i Estonię. Pierwsza oręduje za wartościami demokratycznymi i pokojowym rozwiązywaniem sporów, a druga promuje prawo międzynarodowe i podkreśla kwestię praw człowieka.

W działaniach państw bałtyckich obecna jest taktyka ukrytej podmiotowości. Najpełniej widać ją $\mathrm{w}$ polityce Tallina na forum ONZ i tworzeniu koalicji na rzecz odebrania Mińskowi mistrzostw świata w hokeju na lodzie. Posługiwały się nią także Wilno i Ryga, często działając pod

57 P. Slunkin, A. Shraibman, H. Hubarava, Belarus and the Baltic States: repercussions of the lingering political crisis, The Friedrich Ebert Foundation, Kyiv 2021, s. 17-18: <http:// library.fes.de/pdf-files/bueros/ukraine/18025-20210623.pdf> [dostęp: 18 XI 2021].

58 I. Tarand, Estonia..., s. 12. 
osłoną instytucji Unii Europejskiej. Ze względu na powolność tych ostatnich szukały też wsparcia partnerów w innych formatach, np. Trójkącie Lubelskim i Ósemce Nordycko-Bałtyckiej. Występowały wreszcie wspólnie jako państwa bałtyckie, co można było zaobserwować w nakładaniu sankcji na białoruskich urzędników.

Wszystkie trzy kraje proponowały również dobre usługi, polegające na mediacjach między białoruską władzą a społeczeństwem. Istnieją przesłanki, by dopatrzeć się w działaniach litewskich polityków cichej dyplomacji, w rezultacie której możliwy był wyjazd Swiatłany Cichanouskiej z Białorusi.

Trudno uznać, by Ryǵa wykorzystywała swoje nadmorskie położenie do stosowania względem Mińska dyplomacji przedsiębiorczej. Była to raczej praktyczna rywalizacja z Wilnem o zyski gospodarcze. Można zaryzykować, że spadek obrotów w zakresie usług transportowych to najistotniejszy koszt zaangażowania państw bałtyckich w sprawę białoruską.

Za retoryczne należy uznać pytanie, czy państwa bałtyckie mogły zachować neutralność wobec wydarzeń na Białorusi. Cechująca tę kategorię podmiotów ostrożność i nieprzewidywalność sytuacji w sąsiednim kraju nie pozwalały im na obojętność. U podstaw ich aktywności leżała troska o własne bezpieczeństwo, a jej swoistym wskaźnikiem był poziom zainteresowania poszczególnych społeczeństw. Za najaktywniejszych należy tu uznać Litwinów, a najsłabiej ocenić zaangażowanie Estończyków. Zasadniczo jednak trzeba stwierdzić, że podczas powyborczego kryzysu na Białorusi państwa bałtyckie zaprezentowały szeroką paletę instrumentów i strategii typowych dla małych państw, odważnie i pragmatycznie wykorzystując możliwości wynikające ze swojego położenia, potencjału i uczestnictwa w stosunkach międzynarodowych.

\section{Bibliografia}

Bajda P., Małe państwo europejskie na arenie międzynarodowej. Polityka zagraniczna Republiki Stowackiej w latach 1993-2016, Ośrodek Myśli Politycznej, KrakówWarszawa 2018.

Baltic and Nordic responses to the 2020 post-election crisis in Belarus, ed. A. Sprūds, M. Andžāns, E. Djatkovič, Latvian Institute of International Affairs, March 2021 (Policy Brief).

Baltic nations form human chains in support of Belarus protests, "Deutsche Welle" [online], 23 VIII 2020 [dostęp: 1 V 2021]: 〈https://www.dw.com/en/ baltic-nations-form-human-chains-in-support-of-belarus-protests/a-54667005 $\rangle$. 
Białoruśs wyrzuca ambasadora i prawie caly personel dyplomatyczny Łotwy. Łotwa odpowiada tym samym, „Onet” [online], 24 V 2020 [dostęp: 29 V 2021]: <https:// www.onet.pl/informacje/onetwiadomosci/bialorus-wyrzuca-ambasadorai-prawie-caly-personel-dyplomatyczny-lotwy-lotwa/y41zo3e,79cfc278>.

Djatkoviča E., Latvia, [w:] Baltic and Nordic responses to the 2020 post-election crisis in Belarus, ed. A. Sprūds, M. Andžāns, E. Djatkovič, Latvian Institute of International Affairs, March 2021 (Policy Brief).

Grudziński P., Państwo inteligentne. Polska w poszukiwaniu międzynarodowej roli, Wydawnictwo „Adam Marszałek”, Toruń 2008.

Haugevik K., Kuusik P., Raik K., Nagelhus Schia N., Small states, different approaches. Estonia and Norway on the UN Security Council, International Centre for Defence and Security, Tallinn 2021: <https://icds.ee/wp-content/uploads/2021/11/ICDS_ EFPI_Report_Small_States_Different_Approaches_Haugevik_Kuusik_Raik_ Schia_November_2021.pdf> [dostęp: 18 XI 2021].

Jankowiak M., Tichomirow A., Białoruś trzy miesiące po wyborach prezydenckich, „Przegląa Bałtycki” [online], 24 XI 2020 [dostęp: 1 V 2021]: <https://przegladbaltycki.pl/16839,bialorus-trzy-miesiace-po-wyborach-prezydenckich.html $\rangle$.

Joint Statement of Nordic-Baltic Foreign Ministers on recent development in Belarus, „Republic of Estonia. Ministry of Foreign Affairs", 11 VIII 2020 [dostęp: $1 \mathrm{~V}$ 2021]: <https://vm.ee/en/news/joint-statement-nordic-baltic-foreign-ministersrecent-developments-belarus $>$.

Jurasz W., Turecki K., Polska w światowej ǵrze o Białoruś gra drugie skrzypce, „Onet” [online], 11 VIII 2020 [dostęp: $1 \mathrm{~V} \mathrm{2021]:} \mathrm{<https://www.onet.pl/informacje/}$ onetwiadomosci/bialorus-wybory-prezydenckie-polska-w-swiatowej-grze-gra-drugie-skrzypce/6odb2f5,79cfc278?fbclid=IwAR2DisE4GpTzcceH Krzn 4cn-KJqj6yqmM7ErJLp9TplocxebtKnYErQsqQM $>$.

Kalendarium - sankcje UE wobec Białorusi, „Rada Europejska. Rada Unii Europejskiej” [online], 9 XI 2021 [dostęp: 18 XI 2021]: <https://www.consilium.europa.eu/pl/ policies/sanctions/restrictive-measures-against-belarus/belarus-timeline/ $\rangle$.

Kallaste K., Wright H., Estonian government does not recognize Belarus election results, „Eesti Rahvusringhääling” [online],18 XI 2020 [dostęp: 18.11.2021]: <https://news.err. ee/1125073/estonian-government-does-not-recognize-belarus-election-results $\rangle$.

Kłysiński K., Skazani na wspótpracę. Uwarunkowania relacji Litwy $i$ Łotwy $z$ Białorusią, Ośrodek Studiów Wschodnich, Warszawa 2013 (Komentarze osw, 99).

Kubilius A., Białoruś: kilka uwag $w$ sprawach międzynarodowych, tłum. K. Korzeniewska, „Przegląd Bałtycki” [online], 20 IX 2020 [dostęp: 1 V 2021]: $<$ https://przegladbaltycki.pl/16472,bialorus-kilka-uwag-w-sprawach-miedzynarodowych.html $>$.

Kuczyńska-Zonik A., Międzynarodowa rola Litwy wobec kryzysu na Białorusi, Instytut Europy Środkowej, Lublin 2020 (Komentarze IEŚ, 247).

Kuczyńska-Zonik A., Morze z widokiem na przyszłość. Potencjał i rozwój państw battyckich, Instytut Europy Środkowej, Lublin 2021 (Komentarze IES, 397). 
Kuczyńska-Zonik A., Sankcje Unii Europejskiej wobec Białorusi i ich wpływ na gospodarki Litwy i Łotwy, Instytut Europy Środkowej, [Lublin] 8 VII 2021 (Komentarze IES, 419).

Lebioda D., Wpływ białoruskiej elektrowni jądrowej w Ostrowcu na kraje battyckie, „Przegląd Bałtycki" [online], 19 V 2021 [dostęp: 29 V 2021]: <https://przegladbaltycki.pl/17344,wplyw-bialoruskiej-elektrowni-jadrowej-w-ostrowcu-na-kraje-baltyckie.html>.

Łysek W., Białoruś jako arena rywalizacji mocarstw. Stany Zjednoczone $i$ Chiny wobec projektu integracji Federacji Rosyjskiej i Republiki Białoruś w latach 2019-2020, [w:] Rywalizacja Federacji Rosyjskiej na arenie międzynarodowej i jej konsekwencje dla bezpieczeństwa, red. M. Banasik, Wydawnictwo „Difin”, Warszawa 2020.

Małe państwa Europy. Specyfika systemu politycznego i aktywności międzynarodowej, red. D. Popławski, Oficyna Wydawnicza „Aspra-JR”, Warszawa 2009.

Mardisalu-Kahar M., Estonia and the Eastern Partnership: the view from Tallin, „European Council on Foreign Relations” [online], 19 V 2015 [dostęp: 18 XI 2021]: <https://ecfr.eu/article/commentary_estonia_and_the_eastern_partnership_the_view_from_tallinn3036/ $>$.

Ó Súilleabháin A., Small states at the United Nations. Diverse perspectives, shared opportunities, International Peace Institute, New York 2014: <https://www. ipinst.org/wp-content/uploads/publications/ipi_e_pub_small_states_at_ un.pdf> [dostęp: $1 \mathrm{~V}$ 2021].

Oświadczenie Prezydentów Andrzeja Dudy i Gitanasa Nausédy, „Prezydent” [online], 9 VIII 2020 [dostęp: 1 V 2021]: 〈https://www.prezydent.pl/aktualnosci/wydarzenia/art,1900,oswiadczenie-prezydentow-andrzeja-dudy-i-gitanasa-nausdy.html >.

Paszkowski M., Białoruś i Ukraina: nowy rynek zbytu dla amerykańskiej ropy naftowej, Lublin 2020 (Komentarze IEŚ, 180).

Political relations, "Embassy of the Republic of Belarus to the Republic of Estonia” [online, dostęp: 18 XI 2021]: 〈https://estonia.mfa.gov.by/en/bilateral_relations〉.

Popławski D., Fenomen europejskiego państwa małego. Próba bilansu, [w:] Małe państwa Europy. Specyfika systemu politycznego i aktywności międzynarodowej, red. D. Popławski, Oficyna Wydawnicza „Aspra-JR”, Warszawa 2009.

Presidents of Lithuania, Estonia, Latvia and Poland call for action on Belarus, "President Republic of Estonia” [online], 13 VIII 2020 [dostęp: 1 V 2021]: <https://www.president.ee/en/meedia/press-releases/16115-presidents-of-lithuania-estonia-latvia-and-poland-call-for-action-on-belarus/index.html $>$.

Pukszto A., Stosunki ekonomiczne Białorusi z Litwa $i$ innymi krajami bałtyckimi $w$ kontekście kryzysu migracyjnego oraz inicjatyw dyplomatycznych, [w:] Raport III. Gospodarka w cieniu polityki. Sytuacja ekonomiczna Białorusi, Studium Europy Wschodniej Uniwersytetu Warszawskiego, Warszawa marzec 2021.

Raport I. Białoruś 2021: perspektywa zmiany, Studium Europy Wschodniej Uniwersytetu Warszawskiego, Warszawa marzec 2021.

Raport III. Gospodarka w cieniu polityki. Sytuacja ekonomiczna Białorusi, Studium Europy Wschodniej Uniwersytetu Warszawskiego, Warszawa marzec 2021. 
Raś K., Koniec ostrożnej przyjaźni Litwy z Białorusia, Polski Instytut Spraw Międzynarodowych, Warszawa 2020 (Biuletyn PISM, 205).

Raś K., Państwa bałtyckie wobec elektrowni atomowej w Ostrowcu na Białorusi, Polski Instytut Spraw Międzynarodowych, Warszawa 2020 (Biuletyn PISM, 172).

Rywalizacja Federacji Rosyjskiej na arenie międzynarodowej i jej konsekwencje dla bezpieczeństwa, red. M. Banasik, Wydawnictwo „Difin”, Warszawa 2020.

Slunkin P., Shraibman A., Hubarava H., Belarus and the Baltic States: repercussions of the lingering political crisis, The Friedrich Ebert Foundation, Kyiv 2021: <http:// library.fes.de/pdf-files/bueros/ukraine/18025-20210623.pdf> [dostęp: 18 XI 2021].

Sułek M., Małe państwa europejskie w świetle syntetycznych miar potęgi, [w:] Małe państwa Europy. Specyfika systemu politycznego i aktywności międzynarodowej, red. D. Popławski, Oficyna Wydawnicza "Aspra-JR”, Warszawa 2009.

Szacawa D., Małe państwa Europy Pótnocnej w Radzie Bezpieczeństwa oNZ, Instytut Europy Środkowej, Lublin 2021 (Komentarze IEŚ, 370).

Tarand I., Estonia, [w:] Baltic and Nordic responses to the 2020 post-election crisis in Belarus, ed. A. Sprūds, M. Andžāns, E. Djatkovič, Latvian Institute of International Affairs, March 2021 (Policy Brief).

The UN Security Council to discuss the issue of Belarus tomorrow at Estonia's initiative, „Republic of Estonia. Ministry of Foreign Affairs” [online], 10 XI 2020 [dostęp: $1 \mathrm{~V}$ 2021]: 〈https://vm.ee/en/news/un-security-council-discuss-issuebelarus-tomorrow-estonias-initiative\#: :text=You\%20are\%20here-\%20 $>$.

Usov P., Zadania białoruskiego ruchu demokratycznego w perspektywie końca epoki Łukaszenki, [w:] Raport I. Białoruś 2021: perspektywa zmiany, Studium Europy Wschodniej Uniwersytetu Warszawskiego, Warszawa marzec 2021.

Vilpišauskas R., Lithuania, [w:] Baltic and Nordic responses to the 2020 post-election crisis in Belarus, ed. A. Sprūds, M. Andžāns, E. Djatkovič, Latvian Institute of International Affairs, March 2021 (Policy Brief).

Wilczewski D., Białorusini protestuja, Litwini wspieraja, „Przegląd Bałtycki” [online], 19 VIII 2020 [dostęp: 1 V 2021]: <https://przegladbaltycki.pl/16315,bialorusini-protestuja-litwini-wspieraja.html $>$. 